\title{
Экономический рост в условиях экстрактивных институтов: советский парадокс и современные события ${ }^{1}$
}

\author{
Е.В. БАЛАЦКИЙ*, Н.М. ПЛИСКЕВИЧ**
}

\begin{abstract}
*Евгений Всеволодович Балацкий - доктор экономических наук, профессор, директор Центра макроэкономических исследований, Финансовый университет при Правительстве Российской Федерации. Адрес: 109456, Москва, 4-й Вешняковский проезд, д. 4, офис 219. E-mail: evbalatsky@inbox.ru

**Наталья Михайловна Плискевич - старший научный сотрудник, Институт экономики РАН. Адрес: 117485, Москва, Профсоюзная ул., д. 90. E-mail: ons@naukaran.ru

Цитирование: Балацкий Е.В., Плискевич Н.М. (2017) Экономический рост в условиях экстрактивных институтов: советский парадокс и современные события // Мир России. T. 26. № 4. C. 97-117. DOI: 10.17323/1811-038X-2017-26-4-97-117
\end{abstract}

В статье анализируются экономические успехи СССР в терминах концепции инклюзивныхх институтов, выдвинутой Д. Асемоглу и Дж. Робинсоном. Суть проблемы состоит в том, что трактовки и интерпретации Д. Асемоглу и Дж. Робинсона нельзя признать адекватными для системного объяснения советского парадокса, заключающегося в длительном и интенсивном экономическом росте с элементами опережающего характера на фоне действующчих в стране экстрактивных институтов. Для более точного и полного объяснения данного феномена в статье уточняется и развивается ряд положений теории инклюзивных институтов. В частности, авторы вводят понятия соичильного лифта, трехфакторной модели экономического роста, включающей технологический, институичональный и культурный факторы, правило соответствия, принции диссипации инклюзивности. В статье показано, как новые понятия могут быть использованы при анализе современных событий на примере России и нефтедобывающих стран Ближнего Востока.

Ключевые слова: инклюзивные институты, экстрактивные институты, советская индустриализация, экономический рост, модернизация, социальные лифты

1 Статья выполнена при финансовой поддержке Российского фонда фундаментальных исследований (проект №16-02-00483). 
Получившая в последнее время широкую популярность концепщия инклюзивных институтов (КИИ) Д. Асемоглу (Аджемоглу) ${ }^{2}$ и Дж. Робинсона, объясняющая различия в богатстве и бедности стран и народов господством в них либо инклюзивных, либо экстрактивных институтов (ИИ и ЭИ соответственно), не могла не вызвать живого интереса прежде всего в тех государствах, которые в своей истории неоднократно пытались вырваться на новые рубежи развития. Предложенная авторами концепции инклюзивных институтов схема подкреплена огромным фактическим материалом мировой экономической истории. Она дает объяснения различным нюансам экономического и политического развития в разных уголках земного шара. Среди выдвинутых в последние годы экономических теорий КИИ, по нашему убеждению, является одной из наиболее убедительных и плодотворных.

Повышенный интерес российского аналитического сообщества к КИИ подогревается тем обстоятельством, что Россия - страна, история которой насчитывает не одну попытку модернизации, окончившуюся неудачей. И, что особенно важно, авторы концепции инклюзивных институтов, отводя России на страницах своей книги достаточно много места, на наш взгляд, ошибочно интерпретируют многие события ее истории. Для них опыт СССР интересен лишь как отклонение от общего тренда - наличия экономического роста в условиях господства экстрактивных институтов, которые, согласно их концепции, этот подъем должны блокировать [Аджемоглу, Робинсон 2016, с. 173-184]. Объяснения этому феномену, предложенные в книге, по сути, можно свести к двум тезисам. Во-первых, «большевикам удалось выстроить сильное, централизованное государство и использовать его для перераспределения ресурсов в пользу промышленности» [Аджемоглу, Робинсон 2016, с. 183]. Во-вторых, сам «уровень технологического развития России был настолько ниже европейского и американского, что простое перераспределение ресурсов в пользу индустрии, пусть рассчитанное не оптимально и при этом принудительное, приносило огромные плоды» [Аджемоглу, Робинсон 2016, с. 176]. Этот рост не был связан с техническим прогрессом, а потому не мог стать устойчивым. Закономерным результатом стал и экономический крах СССР.

Признавая справедливость трактовок Д. Асемоглу и Дж. Робинсона в общей характеристике экономической и политической системы СССР как экстрактивной, все же нельзя не заметить множества логических неувязок. В связи с этим в данной статье предпринимается попытка более точного реконструирования истории СССР на основе концепции инклюзивных институтов с введением для этого дополнительных понятий и положений․ Тем самым новое прочтение событий прошлого СССР, по нашему мнению, не отрицает, а дополняет и углубляет эту концепцию. Мы делаем акцент на том положении, что отнесение институтов к «чистым» ИИ или ЭИ всегда весьма условно, особенно для стран, проводящих

\footnotetext{
2 В русском переводе книги [Аджемоглу, Робинсон 2016] дана турецкая форма произношения фамилии одного из соавторов, американского ученого турецкого происхождения. В то же время и в российской литературе, и в общемировой практике господствует написание «Асемоглу». Этой традиции мы будем придерживаться в дальнейшем.

3 Мы сознательно концентрируемся на особенностях институционального анализа в рамках КИИ, так как речь идет именно о полемике с выдвинутыми в ней конкретными положениями. На наш взгляд, рассмотрение, например, аргументов концепции Норта-Уоллиса-Вайнгаста или исследований социокультурных основ модернизации России (см. [Аузан 2007; Аузан, Келимбетов 2012]) в данном случае лишь осложняет анализ, что неизбежно потребует уточнения массы позиций, нецелесообразного в рамках журнальной статьи.
} 
активные реформы. Отчасти это связано с невозможностью существования «полюсных» институтов в чистом виде; в реальности неизбежно возникает ситуация их сосуществования и смешивания с формированием определенного баланса, от которого в конечном счете и зависит, к какому «полюсу» пойдет развитие страны.

\section{Суть теоретических противоречий: догоняющий и опережающий экономический рост}

В своей книге стилизованными примерами Д. Асемоглу и Дж. Робинсон охватили практически всю мировую географию: здесь присутствуют страны Северной и Южной Америки, Африки, Европы, Азии, Австралия, однако, на наш взгляд, самые слабые примеры приведены относительно Советского Союза. И это неудивительно: западные специалисты часто плохо разбираются в специфике экономических отношений в СССР в силу слишком больших отличий этой системы от привычных им капиталистических. В связи с этим авторы допускают три принципиальные ошибки в трактовке событий, касающихся как процесса создания Советского Союза, так и его развала.

Первая ошибка концепции инклюзивных институтов состоит в тезисе о крайней отсталости России до революции 1917 г. Это слишком категоричное утверждение: на рубеже XIX-XX вв. наша страна, как известно, наряду с США была одной из наиболее быстроразвивающихся, а в 1920-е гг. ей удалось восстановить многое из разрушенного в годы Гражданской войны. Вторая ошибка связана с представлением, что в СССР имел место классический экстрактивный режим, который изначально установился в результате произошедшей социалистической революции. Однако события 1917 г. и предшествующего периода свидетельствуют о процессах формирования в стране демократических институтов. Некоторые из них впоследствии были уничтожены, некоторые - деформированы, но все же на всем протяжении истории СССР оставались анклавы, где поддерживались демократические порядки. Это, кстати, было той базой, на которой в кратчайшие сроки смогли развернуться процессы перестройки рубежа 1980-1990-х гг. И, наконец, третья ошибка заключается в утверждении, что главным источником экономического роста в период сталинского правления был волюнтарный переброс крестьян в города и вовлечение их в промышленное производство, которое все годы существования СССР оставалось чуждым научно-техническому прогрессу и по этой причине низкопроизводительным. Однако в это объяснение не укладываются многие известные факты: например, хотя испытанная в 1949 г. советская атомная бомба и была копией американской, но уже вторая атомная бомба, испытанная в 1951 г., принципиально отличалась от нее. К созданию водородной бомбы советские ученые шли двумя путями: американским, основанным на данных разведки и приведшим к тупиковому результату, и собственным, предложенным А.Д. Сахаровым и успешно завершившимся испытанием в 1953 г., т.е. термоядерная бомба в СССР была создана раньше, чем в США. В 1954 г. был осуществлен пуск первой в мире АЭС, что ознаменовало новую эру в энергетике [Кузнецова 2016]. К сказанному можно добавить достижения СССР в сфере освоения космоса - первый искусственный спутник земли (1957 г.), первый полет человека в космос (1961г.), первый 
выход человека в открытый космос (1965 г.) и другие. Такое технологическое опережение не могло быть достигнуто на базе примитивного сгона крестьян в города и их подневольного труда на заводах. В СССР были выстроены мощная индустрия (включая космическую) и диверсифицированная наука, во многих направлениях которой российские специалисты лидировали долгие десятилетия.

В этом пункте анализа следует сделать важное уточнение. Дело в том, что само отношение Д. Асемоглу и Дж. Робинсона к России базируется на постулате о том, что она является типичной страной с режимом догоняющего экономического роста (ДЭР). Именно поэтому Россия оказывается в одном ряду со странами Азии, Африки и Латинской Америки. Однако именно здесь кроется ошибка, поскольку страна с режимом ДЭР по определению не может дать ничего нового по сравнению со странами-лидерами. Даже нынешний Китай пока ничего не представил миру такого, чего не было ранее в США. Между тем в ХХ в. СССР во многих отношениях опередил все страны мира: программа ГОЭЛРО, которая впоследствии была скопирована Соединенными Штатами при электрификации долины реки Теннесси; равные права мужчин и женщин, а также представителей всех национальностей; ликвидация безработицы; всеобщее среднее и бесплатное высшее образование; отмеченные научные и технологические прорывы и т.п. Напомним также о роли русского авангарда как в живописи, так и в музыке, зародившегося еще в дореволюционное время, но достигшего своего расцвета в 1920-е гг, его влияние на развитие всего мирового искусства XX в. общепризнано. К сказанному можно добавить русский балет и театр (К.С. Станиславский, В.Э. Мейерхольд, А.Я. Таиров), блестящих отечественных архитекторов-конструктивистов и прочее. Вполне очевидно, что история СССР богата пионерными достижениями в технологической, институциональной и культурной сферах, то есть явными признаками режима опережающего экономического роста (ОЭР).

Следует отметить, что перечисленные достижения СССР были бы просто невозможны в рамках архаичных и откровенно неэффективных экстрактивных институтов. Следовательно, мы имеем дело с уникальным явлением: страна, обладающая всеми признаками режима ОЭР, не может быть помещена в стандартные рамки концепции инклюзивных институтов. Оговоримся: было бы неверным и утверждение, что СССР устойчиво следовал по пути опережающего экономического роста; скорее, его система также представляла собой смешанный режим - совмещение ОЭР и ДЭР, однако уже этого факта достаточно для вопроса о корректировки КИИ.

Итак, за счет чего же были получены все перечисленные технологические институциональные и культурные достижения страны? Данный вопрос требует более системного объяснения по сравнению с тем, которое дает концепция инклюзивных институтов.

\section{Методология исследования: принцип соответствия}

Чтобы более полно рассмотреть суть советского парадокса, состоящего в наличии длительного и во многом опережающего экономического роста в условиях экстрактивных институтов, следует отталкиваться от принципа соответствия. 
Данный принцип в неявной форме был высказан в статье В.М. Полтеровича «Политическая культура и трансформационный спад. Комментарий к статье Арье Хиллмана “В пути к земле обетованной”» [Полтерович 2002] и еще раз повторен в более поздней публикации «Институты догоняющего развития (к проекту новой модели экономического развития России)» [Полтерович 2016]. В кратком виде этот принцип можно сформулировать следующим образом: экономический рост происходит при эффективных институтах, однако при этом должно соблюдаться довольно строгое соответствие между технологическим, институциональным и культурныл уровнями развития. Если хотя бы один фактор развития оказывается «провальным», то экономический рост становится затруднительным или вообще невозможным.

В свете принципа соответствия становятся особенно отчетливыми те методологические ограничения, которые наложили на себя Д. Асемоглу и Дж. Робинсон в концепции инклюзивных институтов. В аналогичную ситуацию нередко попадают и ученые, стремящиеся выстроить простую и внутренне непротиворечивую модель. В ходе такого построения они обосновывают логичность исключения из нее компонентов, являющихся либо несущественными, либо имеющих к ней лишь косвенное отношение 4 . Д. Асемоглу и Дж. Робинсон даже посвятили специальную главу «теориям, которые не работают», отбрасывая, в частности, и проблемы социокультурного влияния на ход становления институтов. В своем исследовании процессов, происходивших в нашей стране, они игнорировали и принцип историзма: по их мнению, СССР появляется как бы на пустом месте, вне анализа той многовековой истории страны, уже прошедшей и периоды мобилизационных рывков, и медленного эволюционного развития, в ходе которого сквозь экстрактивную основу прорастали инклюзивные институты.

Напомним, что Д. Норт подчеркивал: «Находящаяся в нашем распоряжении структура артефактов - институтов, представлений, орудий, приемов, внешних систем хранения символов - унаследована нами от прошлого. В широком смысле она вообще представляет собой культурное наследие, и мы сильно рискуем, игнорируя ее при принятии решений, рискуем провалом своих попыток повысить экономическую эффективность» [Hopm 2010, с. 224]. И далее: «Понимание культурного наследия общества - необходимое условие для осуществления “выполнимых" перемен. Мы должны иметь не только четкое понимание представлений и убеждений, служащих фундаментом для существующих институтов, но и тех пределов, в рамках которых система представлений поддается изменениям, позволяющим создание более производительных институтов» [Норт 2010, с. 234-235]. В целом Д. Норт видел органическую связь между институтами и человеческим капиталом, сформировавшемся в обществе, отмечая, что последний - «это объем имеющихся у людей знаний, их убеждения, а также институты, создаваемые на основе этих убеждений» [Hopm 2010, с. 79].

4 Тут можно вспомнить полемику самих Д. Асемоглу и Дж. Робинсона с авторами другой известной современной концепции - Д. Нортом, Д. Уоллисом и Б. Вайнгастом, - которых они упрекали в том, что последние сосредоточились на элитах и не уделяют должного внимания обществу в целом, которое в определенных условиях заставляет элиты делиться властью [Асемоглу, Робинсон 2015]. На это Д. Норт и его коллеги в принятых ими рамках своего исследования отвечали, что «низовые движения», о которых говорили Д. Асемоглу и Дж. Робинсон, по сути, отражают борьбу элитных группировок, а потому ими можно пренебречь [Норт, Уоллис, Вайнгаст 2011, c. 408-410]. Кстати, в рассматриваемой книге Д. Асемоглу и Дж. Робинсон говорят больше об элитах, нежели о массах. 
С несколько иной стороны подходят к проблеме А. Алесина и П. Джулиано, которые выступают против «растворения культуры внутри системы институтов», как это фактически происходит у Д. Асемоглу и Дж. Робинсона. Они замечают: «С точки зрения семантики мы находим контрпродуктивным и сбивающим с толку отнесение культуры (ценностей и убеждений) к неформальным институтам. На наш взгляд, путаницу создает навешивание ярлыка "институт" на все - от, скажем, уровня взаимного доверия в обществе до конституционных правил системы голосования. Очевидно, < ..> культура (или неформальные институции) и формальные институты взаимосвязаны <...>. Как только мы согласимся, что формальные и неформальные институты взаимосвязаны и что одни могут порождать другие, определение конкретных ценностей или убеждений как культуры или неформальных институтов становится лишь вопросом семантики» [Алесина, Джулиано 2016, с. 87-88].

Нельзя не упомянуть и Л. Харрисона, который противопоставляет «универсальной культуре прогресса» «универсальную крестьянскую культуру», подчеркивая, что «культурный детерминизм - идея, что неизменная во времени культура пересиливает все прочие факторы и диктует траекторию, по которой общество или страна с неизбежностью будут следовать, - нежизнеспособен ни как теория, ни как практика» [Харрисон 2014, с. 54].

Приведенные высказывания видных исследователей самых разных направлений социально-экономической мысли позволяют усомниться в верности идеи Д. Асемоглу и Дж. Робинсона об абстрагировании от культурного компонента при создании ими своей институциональной конструкции. Можно признать такое абстрагирование при определении специфики экстрактивных и инклюзивных институтов, однако при переходе к анализу их функционирования в реальной среде (особенно в ситуации попыток эволюции одного типа институтов в другой) социокультурный компонент оказывается той аурой, которая «обволакивает» весь процесс и часто в решающей степени влияет на его результат.

Особенно важно учитывать принцип соответствия для такой страны, как Россия. Не будем забывать, что наша страна прошла целый ряд неудачных попыток модернизации мобилизационного типа. Собственно, об одной из таких попыток и пишут Д. Асемоглу и Дж. Робинсон, рассуждая о причинах быстрого экономического роста в СССР. При этом они справедливо отмечают, что подобная попытка предполагает укрепление имеющихся экстрактивных институтов. Однако стоило бы добавить, что связанное с мобилизационными рывками укрепление этого типа институтов имеет и долгосрочные отрицательные последствия, формирует в институциональной ткани общества особого рода «рубцы», незнакомые странам, которые прошли свой путь развития эволюционным путем, и создающие дополнительные трудности при очередных попытках выстраивания системы инклюзивных институтов, даже если эти новые попытки отстоят от времени создания таких «рубцов» на десятилетия или даже столетия [Плискевич 2016].

Таким образом, успехи и неудачи в развитии СССР следует искать не только в типе господствовавших в нем институтов, но в их соответствии или, наоборот, несоответствии технологическим и культурным детерминантам. Только анализ процесса сопряжения этих трех факторов социального развития (технологий, институтов и культуры) может обеспечить удовлетворительное объяснение советского парадокса. С этой целью рассмотрим феномен СССР последовательно - по фазам его создания, расцвета и упадка. 


\section{Возникновение СССР: \\ начальные условия институционального строительства}

Авторы концепции инклюзивных институтов утверждают, что в СССР имел место классический экстрактивный режим, который изначально установился в результате произошедшей социалистической революции. Однако это не совсем верно: революция 1917 г. стала реакцией на целый комплекс разнонаправленных процессов. С одной стороны, в течение полувека в стране в ходе эволюционных реформ создавались зачатки инклюзивных институтов. В различных сферах этот процесс шел с разной скоростью, результаты его также были неодинаковы, и само это различие провоцировало рост напряжения в обществе. С другой стороны, господствующая традиционалистская социокультурная среда (опора экстрактивных институтов) сопротивлялась реформаторским процессам. Причем это противодействие шло как снизу (прежде всего со стороны крестьянских масс, чья привычная жизнь была связана со старыми общинными порядками), так и сверху, со стороны властных элит, стремящихся к переделу ресурсов в свою пользу или, как минимум, к сохранению старых пропорций распределения. Как всегда, в таких случаях образуется значительный слой «промежуточных выгодополучателей», использующих состояние незавершенности реформ и пытающихся затормозить их на выгодном им этапе (об этом феномене нам следует думать и сегодня). Тяготы войны усилили эти перераспределительные настроения, и царское правительство в 1915-1916 гг. предприняло ряд регулятивных шагов, вполне соответствующих логике действий будущего советского правительства [Жаворонков, Яновский 2016]. Такая политика укрепила недовольство всех слоев населения, в которое входили и страты, выступающие за возвращение к традиционалистским устоям, и набирающие силу страты, ориентированные на модернизацию. Причем под воздействием модных тогда идеологических течений, берущих начало от А.И. Герцена, прогресс общества в представлении многих из нацеленных на модернизацию связывался с понятием «социализм». То, что оно будет извращено большевистской трактовкой, стало понято позднее, но сама идея служения народу, создания нового, более справедливого общества была очень сильна.

Именно поэтому на сторону революции перешли многие представители военной элиты, позволившие создать эффективную Красную Армию, а затем и дееспособные органы государственного управления, равно как и инженеры, ученые, деятели культуры, сознательно вставшие в ряды строителей нового общества. Таким образом, условие наличия широкой оппозищионной коалищии, диктуемое КИИ для перехода к инклюзивным институтам, в СССР было выполнено.

Нельзя также не учитывать, что полвека эволюционных реформ середины $\mathrm{XIX}$ - начала XX в. привело к серьезным сдвигам в социальной структуре предреволюционного общества. Прежде всего важно отметить появление новой массовой страты - рабочего класса. Правда, шел лишь процесс его формирования (кадровые рабочие составляли только $50 \%$ его численности [Миронов 2000, т. 1, с. 343], а для основной его массы, тесно связанной с деревней, условия жизни и труда были предельно тяжелыми, что порождало излишнюю политизированность этой массы, несвойственную их западным собратьям [Миронов 2017]). Но, несмотря на незавершенность сдвигов в социальной структуре, массовые преобразования в этой 
области становились бесспорными, причем эти трансформации свидетельствовали о создании условий для формирования инклюзивных институтов. Следовательно, и второе условие перехода к инклюзивным институтам (наличие нового влиятельного прогрессивного класса) отчасти было осуществлено. Разумеется, речь тут может идти лишь о начале процесса, который, как мы знаем, в итоге окончился неудачей, однако и отрицать факт подобных предпосылок также было бы грубой ошибкой.

Наконец, было выполнено и третье условие (существование плюралистической системы сдержек и противовесов). Итогом Первой русской революции (1905-1907 гг.), подорвавшей царский режим, стала октроированная конституция, подписанная Николаем II в форме Манифеста от 17 октября 1905 г. и даровавшая гражданские свободы на началах неприкосновенности личности, свободы совести, слова, собраний и союзов; также был учрежден парламент, состоящий из Государственного Совета и Государственной Думы.

В начале 2017 г. Февральская революция привела к свержению российского самодержавия. Правда, слабость правящей элиты создала ситуацию двоевластия Временного правительства и системы Советов. Лишь после октябрьского переворота руководство страной перехватили исполнительные органы большевиков Совет Народных Комиссаров, который вскоре, разогнав Учредительное собрание, узурпировал власть на подконтрольной ему территории, распространившуюся на всю страну только после Гражданской войны.

Таким образом, на первых этапах существования нового государства Советов (при всех издержках, связанных с реалиями войны и жесткой классовой борьбы) имелись шансы для классического перехода от экстрактивных к инклюзивным институтам (что выразилось, в частности, в политике НЭПа). Несмотря на большевистский террор, продолжавшийся и после Гражданской войны, можно привести массу свидетельств того, что в 1920-е гг. широкие массы получили беспрецедентно свободный доступ к любым профессиям и даже государственным должностям. Перед людьми искусства также открылись значительные возможности самовыражения 5 . Иными словами, Советский Союз в начале своего существования представлял собой сочетание экстрактивных и инклюзивных институтов в рамках однопартийной системы, и наличие такого «смешанного» институционального режима становится принципиальным для осмысления первой ошибки Д. Асемоглу и Дж. Робинсона.

\section{Первые успехи СССР: роль человеческого капитала}

Основы инклюзивных институтов в СССР не могли возникнуть на пустом месте, фактически данное событие во многом предопределялось созданными в царский период резервами человеческого капитала весьма высокого качества, востребованными быстрым развитием страны на пути эволюционных реформ.

\footnotetext{
5 Вспомним, что русский авангард, оказавший влияние на развитие всего мирового искусства XX в., хотя и зародился в дореволюционной России, особых высот достиг именно в первые революционные и постреволюционные годы.
} 
Процесс накопления этого капитала связан с той спецификой социокультурного развития нашей страны, которая позволила А.С. Ахиезеру определить российскую цивилизацию как «промежуточную», с ее «мучительной неспособностью выйти за рамки промежуточного состояния» [Ахиезер 1998, с. 360]. Эту цивилизацию А.С. Ахиезер трактует как особую переходную форму от традиционной суперцивилизации (т.е. общества с господством экстрактивных институтов и инверсионной логикой мышления людей) к суперцивилизации либеральной (соответственно, с системой инклюзивных институтов и медиационным типом мышления) [Ахиезер 1997; Ахиезер 1998]. А.С. Ахиезер пишет, Россия «“застряла” между этими двумя суперцивилизациями, так как ценности этих суперцивилизаций раскололи страну» [Ахиезер 1998, с. 360-361]. В книге «Россия: критика исторического опыта» на материале всей истории страны показано, как страна регулярно делала мучительные попытки перейти к продвинутой медиационной логике и преодолеть раскол между двумя суперцивилизациями. Но это всегда заканчивалось тем, что Россия вновь оказывалась отброшенной назад, в сторону традиционализма, или экстрактивных институтов. Ликвидировать такое патологическое состояние, по мнению А.С. Ахиезера, можно «либо путем преодоления раскола и перехода к либеральной суперцивилизации, либо в результате деградации и гибели общества» [Ахиезер 1998, с. 331].

В общественном же организме раскол выражается в происходившем уже не одно столетие разделении российского социума на традиционалистское большинство и тонкую прослойку сторонников либеральных ценностей, причем, несмотря на все сложности, откаты назад, эта немногочисленная страта пусть медленно, но росла. И именно с ней были связаны люди, начавшие не только отстаивать соответствующие ценности, но и ментально созревшие для формирования инклюзивных институтов в обществе, где господствовали институты экстрактивные. Своим нестандартным мышлением они были способны в ситуации краха очередной попытки эволюционного преобразования институтов еще некоторое время поддерживать элементы инклюзивности, оживляя с их помощью внутренне чуждые им экстрактивные институты.

Как представляется, именно в подобной ситуации имеет смысл искать основные причины экономических успехов СССР в годы первых пятилеток. Не следует забывать и о полувековом дореволюционном пути России, в ходе которого элементы инклюзивных институтов развивались внутри общего экстрактивного режима. А самое главное, появился достаточно значительный слой людей, способных не только действовать в условиях инклюзивных институтов, но и создавать их 6 . Этому способствовала новая система образования, позволившая привлекать талантливых представителей широких слоев общества (таблица 1). Сложившаяся ситуация благоприятствовала интенсивному росту среды с качеством человеческого потенциала, соответствующим требованиям формирования инклюзивных институтов.

\footnotetext{
6 О качестве человеческого потенциала, накопленного до 1917 г. в России, косвенно может свидетельствовать и то, что многие будущие эмигранты смогли вписаться в инклюзивные институты Запада. А отдельные представители эмиграции составили гордость мировой науки (вспомним, например, И. Сикорского и В. Зворыкина, П. Сорокина и В. Леонтьева).
} 
Таблица 1. Социальное происхождение учащихся гимназий и университетов, \%

\begin{tabular}{|c|c|c|c|c|c|c|c|c|c|}
\hline \multirow{2}{*}{ Сословие } & \multicolumn{4}{|c|}{ Мужские гимназии } & \multicolumn{5}{|c|}{ Университеты } \\
\hline & 1863 & 1880 & 1898 & 1914 & 1863 & 1880 & 1895 & 1914 & 1914* \\
\hline Дворянство & 73,1 & 52,1 & 52,2 & 32,5 & 64,6 & 46,6 & 45,4 & 35,9 & 29,2 \\
\hline Духовенство & 2,8 & 5,1 & 3,4 & 7,1 & 8,3 & 23,4 & 4,9 & 10,3 & 3,8 \\
\hline Горожане & - & 31,6 & 34,6 & 37,4 & 23,5 & 21,5 & 40,9 & 35,3 & 42,0 \\
\hline Крестьянство & - & 6,9 & 7,1 & 20,0 & 1,6 & 3,3 & 6,8 & 14,5 & 20,8 \\
\hline Прочие & 24,1 & 4,3 & 2,7 & 3,0 & 2,0 & 5,2 & 2,0 & 4,0 & 4,2 \\
\hline
\end{tabular}

* Состав учебных заведений технического профиля. Источник: [Миронов 2000, т. 1, с. 139].

В дальнейшем, несмотря на все потери, связанные с войнами 1914-1922 гг., революцией, «красным террором» и эмиграцией, в стране оставалась масса людей, способных соответствовать требованиям и развернувшейся индустриализации, и задачам «культурной революции»: под руководством этих специалистов строились новые заводы, затем они успешно осуществляли сам производственный процесс. Нередко к удивлению своих начальников, отобранных по принципу «преданности идее», эти люди встраивали в общую систему черты инклюзивности. В 1935 г. в своих воспоминаниях начальник строительства Кузнецкого металлургического комбината С.М. Франкфурт особо подчеркивает стиль руководителя монтажных работ, направленного на комбинат именно в связи со срывом этих работ и пресекавшего любые проявления непрофессионализма. «В отличие от других участков работ, у него был создан крепкий технологический отдел. Любую работу он сначала продумывал до конца, составлял на нее технический план и только после этого приступал к делу. < .. > Делать работу на глазок он всегда отказывался. Обычно сдержанный и спокойный, он при этом начинал нервничать и сердиться. $<\ldots>$ Он сам следил за работами и постоянно требовал тщательности. Он был строг к техническому персоналу, его побаивались, а старые мастера - те даже недолюбливали и критиковали за то, что у него “все уж слишком по чертежам, слишком продумано в кабинетах". $<\mathrm{OH}>$ всегда заставлял начатую работу доводить до конца, обязательно до самого конца» [Франкфурт 1935, с. 104-105]. Причем из текста книги видно, что для начальника строительства столкновения архаичной деловой культуры с культурой индустриального общества, по сути, необходимой для дальнейшего развития, предстают чем-то необычным, отклоняющемся от рабочей нормы.

Важно и то, что люди, накопившие еще в дореволюционные годы соответствующий человеческий потенциал, обладали не только необходимыми знаниями: многих захватил искренний энтузиазм, связанный с идеей строительства нового общества. Не надо забывать, что дореволюционное поколение отечественных интеллигентов формировалось в атмосфере служения народу и мечты о новом 
справедливом обществе. Этот мотив служения нередко заглушал то отторжение, которое вызывал политический тоталитаризм большевиков и, по сути, позволял выживать в сложившихся условиях.

Сказанное вполне вписывается в ситуации, связанные с образовательной и научной деятельностью, и в этих сферах ведущая роль принадлежала тем, кто еще до революции получил как минимум гимназическое образование. Именно они составили костяк учителей, благодаря которым удалось в достаточно короткий период осуществить «культурную революцию». В результате новая индустрия получила достаточное количество рабочих, обладавших пусть минимумом знаний, но все же достаточным для освоения массовых индустриальных профессий. Вливавшиеся в их ряды молодые люди, искренне преданные официальной идеологии и начинавшие свою трудовую деятельность в качестве инженеров, учителей, ученых, были прямыми учениками тех представителей старой культуры, которые столь же самоотверженно трудились на благо страны.

С началом индустриализации и развалом в ходе коллективизации деревни жизнь рабочих оставалась крайне тяжелой, но, как продемонстрировал в своем недавнем исследовании Б.Н. Миронов, разрыв в качестве жизни рабочей семьи по сравнению с жизнью семьи деревенской перестал быть столь существенным, как до революции (прежде всего вследствие бедствий деревни, связанных с коллективизацией). Ранее существовавший разрыв в качестве жизни не позволял, в частности, многим пришедшим в город из деревни вчерашним крестьянам заводить семьи, а это, в свою очередь, было одной из причин социально-психологического дискомфорта, присущего дореволюционной рабочей массе [Миронов 2017]. K тому же всеобщее образование, хотя бы в объеме начальной школы, способствовало новому пониманию тех задач, которые ставила перед рабочими развивающаяся индустрия. Напомним в этой связи высказывание Д. Норта: «Специализированные знания приобретают высокую ценность лишь в том случае, когда их можно интегрировать со вспомогательными знаниями ценой небольших затрат» [Hopm 2010, с. 173]. В данном случае с совершенной очевидностью можно констатировать некие зачатки инклюзивности, которые способствовали поддержке экстрактивных по своей сути институтов.

Столь же важная роль носителей качеств, соответствующих требованиям инклюзивных институтов, отмечается и в сферах высшего образования и науки 1920-1940-х гг. Говоря о подготовке новых научных и педагогических кадров и специалистов в других областях, необходимо указать на две противоположные тенденции. С одной стороны, благодаря вновь открывшимся возможностям многие талантливые молодые люди смогли получить качественное образование, стали впоследствии специалистами высокого класса. В то же время академик М.Л. Гаспаров справедливо отмечал, что с наступлением советского периода «культура распространяется не вглубь, а вширь, образованность мельчает» [Гаспаров 2008, с. 192]. Иными словами, экстенсивные процессы, призванные, казалось бы, вывести образование и науку на новые качественные рубежи, в основе своей несли зерна примитивизации. С другой стороны, стремление обеспечить преимущество «социально близким элементам» в получении образования пагубно сказывалось на самом процессе: по сути, исходя из идеологических соображений, фиктивные дипломы выдавались «выдвиженцам», сдававшим экзамены «бригадным методом». Затем эти «выдвиженцы» как активные члены ВКП(б) получали руководящие 
должности, и можно лишь догадываться, сколько грамотных инициатив они загубили. Известна, например, пагубная роль Т.Д. Лысенко в истории отечественного земледелия и биологической науки. Так, в письме, адресованном наркому земледелия А.А. Андрееву, всемирно известный ученый, академик ВАСХНИЛ Д.Н. Прянишников отмечал, что у «народного академика» «невероятное отсутствие образования в области основного естествознания. <.. > Сам он совершенно не сознает этого и вместо того, чтобы учиться, он наклонен только поучать других. $<\ldots>$ Это объясняется тем, что Т.Д. Лысенко не прошел нормального курса высшей школы, он сдавал экзамены в качестве заочника в конце 1920-х гг., когда допускались всякие поблажки. <...> Поэтому ему следовало бы прежде всего пройти физику, химию и ботанику, хотя бы в объеме, отвечающему первому курсу СХА» (цит. по [Соловьев 1995, с. 199]).

Описанные тенденции, равно как последствия террора и огромные потери в Великой Отечественной войне, не могли не сказаться на качественных и особенно количественных характеристиках узкого слоя, который создавал «ауру», необходимую для инноваций, т.е. всего того, что в ситуации господства экстрактивных институтов создавало некий духовный заменитель инклюзивности. Именно этому узкому слою мы в первую очередь обязаны и успехами индустриализации, и развитием ряда отраслей науки (прежде всего связанных с военными нуждами), и прорывом в космос, и удачами в гуманитарных науках, по достоинству оцененных зарубежными коллегами.

Однако длительное существование зачатков инклюзивности в рамках жесткой экстрактивной политической системы не могло продолжаться бесконечно, и для России в качестве своеобразного рубежа можно указать период 1960-х - начала 1970-х гг, вобравший в себя целый ряд факторов. В первую очередь, по-прежнему экстенсивно развивающейся промышленности на уже привычной технологической основе требовалось больше рабочей силы низкой и средней квалификации. До 1950-х гг. ее приток обеспечивала деревня, но к середине XX в. этот источник практически иссяк. Тем временем рост потребности в этих ресурсах стал причиной смены приоритетов в оплате труда; относительно высокие доходы в сферах, предполагающих более квалифицированный труд и в целом занятых развитием человеческого капитала, начали постепенно сокращаться, причем особо резко эти изменения происходили в сфере науки (таблица 2). Как отмечает академик Ю.А. Рыжов, наша «технология отстала еще с начала 1970-х гг., когда резко упали ассигнования на НИОКРы, даже в оборонной промышленности» [Рыжсов 2016]. Кроме того, 1950-1960-е гг. стали временем ухода из жизни того поколения, которое получило и общекультурный, и образовательный фундамент до революции и долгие годы поддерживало «инклюзивную ауру».

В итоге, лишившись поддержки размываемой «инклюзивной ауры», экстрактивный советский режим хотя и смог продержаться благодаря рентным доходам от нефти и газа еще более 10 лет, в конце концов потерпел крах. И главное: его последние десятилетия не были отмечены успехами в областях науки, новых технологий и т.п. Однако, с другой стороны, такие свершения имели место в истории России и в гораздо более сложные и даже трагические периоды, когда за счет инклюзивного по своему духу человеческого капитала даже в условиях господства экстрактивных институтов страна демонстрировала мощный экономический рост. 
Таблица 2. Отношение отраслевых уровней заработной платы к средней по народному хозяйству, \%*

\begin{tabular}{|l|c|c|c|}
\hline Отрасль & $\mathbf{1 9 4 0}$ & $\mathbf{1 9 6 0}$ & $\mathbf{1 9 8 7}$ \\
\hline Промышленность & 103 & 114 & 109 \\
\hline в том числе рабочие & 93 & 109 & 108 \\
\hline служащие & $\mathbf{1 6 1}$ & $\mathbf{1 4 5}$ & $\mathbf{1 1 5}$ \\
\hline Сельское хозяйство & 70 & 68 & 98 \\
\hline Строительство & 110 & 115 & 127 \\
\hline Транспорт & 105 & 110 & 118 \\
\hline Торговля & $\mathbf{7 8}$ & $\mathbf{7 3}$ & $\mathbf{7 2}$ \\
\hline ЖКХ, непроизводственные виды бытового обслуживания & 79 & 72 & 76 \\
\hline Здравоохранение, физкультура и социальное обеспечение & $\mathbf{7 7}$ & $\mathbf{7 3}$ & $\mathbf{7 1}$ \\
\hline Образование & $\mathbf{1 0 0}$ & $\mathbf{9 0}$ & $\mathbf{8 2}$ \\
\hline Культура & $\mathbf{6 7}$ & $\mathbf{6 1}$ & $\mathbf{6 0}$ \\
\hline Искусство & $\mathbf{1 1 8}$ & $\mathbf{7 9}$ & $\mathbf{7 4}$ \\
\hline Наука и научное обслуживание & $\mathbf{1 4 2}$ & $\mathbf{1 3 7}$ & $\mathbf{1 0 7}$ \\
\hline Аппарат органов государственного управления & $\mathbf{1 1 8}$ & $\mathbf{1 0 7}$ & $\mathbf{9 3}$ \\
\hline
\end{tabular}

*Рассчитано по: [Народное хозяйство СССР 1988, с. 390-391].

\section{Длительность успеха ССCP: инклюзивность vs экстрактивность}

Утверждение о длительности экономических успехов СССР требует дополнительного объяснения. На наш взгляд, для этого необходимо внести уточнения в понятия инклюзивных и экстрактивных институтов. Во-первых, ИИ основаны на конкурентном рынке труда, когда наиболее талантливые и работоспособные лица получают лучшие места в бизнесе, на государственной службе и т.д; ЭИ, наоборот, базируются на монопольном рынке труда, когда привлекательные рабочие места закрепляются за строго определенными людьми, попавшими в состав элиты независимо от их способностей, заслуг и достижений. Во-вторых, проявлением и отчасти самим критерием ИИ служит система развитых соичальных лифтов (СЛ). Если для инклюзивных институтов характерно наличие СЛ, когда способный человек получает хорошее образование, а затем достойную работу и положение в обществе, то в условиях экстрактивных институтов социальные лифты блокируются теми, кто имеет возможность пользоваться ими по личностным или идеолого-политическим причинам. Тогда усилия наиболее талантливых индивидов, не входящих в круг избранных, не приводят к изменению их социального положения, поскольку все ключевые посты занимаются по признаку принадлежности к элите.

Введенные уточнения проясняют смысл главных понятий концепции инклюзивных институтов: инклюзивные институты направлены на вовлечение народных масс в создание и распределение материального и духовного богатства, тогда как экстрактивные институты предполагают извлечение элитами сверхдоходов и всех 
видов благ из создаваемого массами богатства. С точки зрения введенного признака наличия социальных лифтов построенные в СССР институты на начальном этапе имели признаки инклюзивных, и за счет их функционирования в раннем СССР многие выдающиеся ученые, деятели культуры и политические деятели могли подняться по социальной лестнице 7 В то время в стране действовала довольно справедливая и эффективная система отбора талантов и кадров на ключевые позиции ${ }^{8}$. Люди, достигавшие серьезных результатов в сфере науки, культуры и производства, имели разумный материальный достаток (хорошую квартиру, машину, дачу), устойчивую работу и возможность творчества. Именно такой набор благ и позволял им самоотверженно трудиться, достигая блестящих результатов в выбранной области. Можно сказать, что экономические и технологические достижения Советского Союза есть прямое следствие вплетения в социальную ткань общества подобных элементов инклюзивности.

Сказанное позволяет усомниться в утверждении Д. Асемоглу и Дж. Робинсона о том, что советский режим был заведомо экстрактивным. Думается, что при всех признаках, прежде всего касающихся политической сферы (подавление политической оппозиции), полностью экстрактивным он не был. В нем присутствовали инклюзивные элементы экономических институтов; особенно это касалось отраслей, связанных с приоритетной для власти военно-промышленной сферой. В этом случае во имя получения нужных результатов правящая элита готова была пойти на некоторые послабления, и в экстрактивной по своей сути конструкции допускала некоторые анклавы с элементами инклюзивности ${ }^{9}$. В противном случае никакая мобилизационная экономика и силовое давление сверху не смогли бы обеспечить ни научно-технические успехи, ни продолжительный экономический рост в стране, который даже по самым строгим оценкам длился около полувека. Тем самым случай СССР прекрасно вписывается в концепцию инклюзивных институтов, но совсем не так, как это сделали Д. Асемоглу и Дж. Робинсон: Советский Союз достиг впечатляющих экономических успехов за счет того, что в нем был построен и действовал на протяжении примерно 50 лет симбиоз экстрактивHblx и инклюзивнblх институтов. Хотя существовавшие идеологические ограничения на карьерный рост и сдерживали инклюзивность в сфере экономических институтов, но они не отменяли ее вовсе.

Наличие достаточного потенциала инклюзивности советских институтов, во многом связанного с дореволюционной историей страны, на протяжении долго-

\footnotetext{
7 Напомним, например, что математик А.Н. Колмогоров (1903-1987), не получивший полноценного школьного образования, смог стать профессором МГУ в 28 лет, а академиком АН СССР - в 35 лет. Похожие результаты продемонстрировал астрофизик В.А. Амбарцумян (1908-1996): приехав в столицу из Грузии с плохим русским языком, стал доктором наук в 28 лет, членом-корреспондентом АН СССР - в 31 год, а академиком - в 45 лет. Таких примеров можно привести великое множество, и никакие исходные семейные позиции не мешали людям совершать головокружительную вертикальную профессиональную ротацию.

8 Здесь мы не имеем в виду тот тип лифтов, который был связан с массовыми репрессиями, когда руководящие посты освобождались вследствие физического устранения занимавших их людей и нередко передавались «без лести преданным» бездарностям. Эти процессы лишь разъедали ту тонкую «инклюзивную ауру», которая существовала в стране и способствовала укреплению экстрактивности как основного вектора ее развития.

9 Классическим примером послаблений советского режима в пользу экономической инклюзивности и принципа конкурентности могут служить созданные и сохранившиеся до сих пор авиационные конструкторские бюро: ОКБ им. П.О. Сухого, Авиационный комплекс им. С.В. Ильюшина, Конструкторское бюро «Туполев». Соревнование этих центров разработки новой авиатехники сегодня уже стало легендарным.
} 
го времени позволяло не просто использовать, но и отчасти воспроизводить качественный человеческий капитал, ориентированный на созидательную деятельность, иначе экономический подъем был бы просто невозможен.

\section{Распад СССР: диссипация инклюзивности}

Следующий вопрос, нуждающийся в системном объяснении, состоит в том, почему распался СССР. Ответ Д. Асемоглу и Дж. Робинсона гласит, что все экстрактивные режимы со временем «сдуваются» и проигрывают экономическое соревнование с инклюзивными режимами, однако Советский Союз, строго говоря, нельзя назвать исключительно экстрактивным режимом.

Адекватный ответ на поставленный вопрос требует некоторых теоретических комментариев. Дело в том, что в институциональной сфере действует правило диссипации инклюзивности (ПДИ), которое можно сформулировать следующим обра3ом: в консервативной социальной системе, обладающей низкой динамичностью развития, с течением времени происходит истощение (рассеивание) потенциала инклюзивности действующих институтов. Иными словами, все ИИ со временем склонны к преобразованию в ЭИ ${ }^{10}$.

Следует отметить, что для поддержания инклюзивных институтов требуется сохранение меритократии и работоспособности социальных лифтов, которые, в свою очередь, диктуют наличие квалифицированных кадров. Однако, согласно концеепции старых рынков [Балацүкий 2010], динамика всех рынков подчиняется логистической кривой: сначала наблюдается бурный рост производства, затем его ослабление с переходом к полному насыщению спроса. На последней стадии жизни рынка необходимые нововведения сделаны и внедрены, все специалисты обучены работе с новым товаром, а потребительский рынок насыщен им полностью. На этом этапе рынок становится «старым», деградирует (стагнирует) и, как правило, погибает либо медленно функционирует на уровне сведения концов с концами. Для предотвращения данного развития событий есть только один способ - постоянное рыночное обновление, т.е. формирование новых рынков, что заново запускает весь экономический цикл и создает новую волну спроса на талантливых и компетентных работников.

При капитализме продуктовые и технологические инновации генерируются конкуренцией и стремлением повысить доходность капитала, тогда как при социализме такие естественные, почти автоматические механизмы, стимулирующие создание новых рынков, отсутствуют. Именно этим можно объяснить крушение $\mathrm{CCCP,} \mathrm{т.е.} \mathrm{потерей} \mathrm{динамичности} \mathrm{развития.} \mathrm{После} \mathrm{завершения} \mathrm{индустриализации}$ и урбанизации, создания научного сектора и ВПК потребность в талантах если и не отпала полностью, то стала менее насущной. Иллюстрацией данного тезиса служат данные таблицьы 2 о сокращении с 1940 по 1987 г. относительного уровня оплаты труда служащих в промышленности, работников сфер искусства, образования и, особенно, науки. Поддержание системы уже не требовало отбора лучших и могло быть обеспечено простой лояльностью рядовых исполнителей; социум

10 У данного правила есть свой аналог в физике в виде закона возрастания энтропии в замкнутых системах. 
начал превращаться в закрытую кадровую систему. Именно с этого момента запускается процесс перерождения советских институтов с элементами инклюзивности в позднесоветские эксрактивные институты.

Был ли этот процесс заранее предопределен? Представляется, что такая заданность все же была, и связана она с тремя важными обстоятельствами. Первое - наличие однопартийной cuстемы, что исключало какую бы то ни было политическую конкуренцию и ослабляло обратные связи системы управления. Второе - отсутствие эффективного механизма передачи власти с учетом ее преемственности. Приход нового лидера государства происходил в результате его победы во внутрипартийной борьбе, а не в результате открытой политической конкуренции. Это приводило к радикальному развороту политики партии и страны: так произошло и в момент смены И.В. Сталина Н.С. Хрущевым, и после следовавших друг за другом Л.И. Брежнева, Ю.В. Андропова и К.У. Черненко, когда к власти пришел «реформатор» М.С. Горбачев. Третье - слишком большие полномочия и чрезмерно крепкие позиции политических лидеров, блокировавшие любые возможности критики их позиций, воспринимавшиеся как антигосударственные. Наличие таких изначальных институциональных изъянов в системе государственного управления обрекало построенные институты на деградацию и цементирование экстрактивности.

Накапливающееся «старение» передовых рынков (индустрии, науки, ВПК, высшего образования) и придание всем процессам массового характера с соответствующей потерей качества постепенно привели к эрозии человеческого капитала. Тот культурный Ренессанс, который наблюдался в течение 50 лет до революции 1917 г., позволил стране подготовить широкие слои образованных людей, выступивших в качестве творцов новых прогрессивных институтов или хотя бы их зачатков. После революции в кругах высшего политического руководства, несмотря на всю его идеологизированность, оставался здоровый прагматизм, подсказывающий необходимость быстрого индустриального развития. Для этого было признано необходимым привлечение «буржуазных спецов» - по сути, интеллектуальной элиты, взращенной предшествующим этапом эволюционного развития страны. Данное обстоятельство выступило залогом успеха при конструировании экономических институтов с элементами инклюзивности, прежде всего в тех областях, в развитии которых руководство было заинтересовано. В последующие 50 лет исходный человеческий потенциал постепенно истощился; система же массового образования СССР была нацелена на поддержание «конвейерной культуры», сковывалась разного рода ограничениями, а энтузиазм строительства нового общества, утопичного по своей сути, быстро сошел на нет.

\section{Инклюзивные и экстрактивные институты в новейшей истории}

Введенные понятия институциональной теории дают возможность по-новому оценить многие современные явления; по крайней мере, на современном этапе можно довольно четко идентифицировать экстрактивные режимы. Это имеет значение при анализе ситуации, например, в нефтедобывающих странах Ближнего Востока. Зададимся простым вопросом: в Саудовской Аравии, ОАЭ и Кувейте действующие 
институты являются инклюзивными или экстрактивными? С одной стороны, в этих государствах рентные нефтяные доходы распределяются довольно справедливо и охватывают практически все коренное население, распространяясь на широкий спектр услуг - образование, здравоохранение, жилье и т.п. С другой стороны, движение по карьерной вертикали в этих странах практически исключено, если человек не входит в правящий семейный клан. Именно второе обстоятельство позволяет классифицировать экономические институты Ближнего Востока как экстрактивные, хотя и с некоторыми признаками инклюзивности; политические же институты, основанные на родоплеменном доминировании, однозначно являются экстрактивными.

Признак наличия социальных лифтов позволяет понять и динамику инклюзивности в США, где в последние три десятилетия наблюдается рост социального неравенства и наметилась консервация политической элиты. Фактически эти процессы недвусмысленно сигнализируют, что и в такой стране, как США, признанном символе инклюзивных институтов, потенциал инклюзивности со временем (по мере снижения динамичности развития) может начать истощаться. Иными словами, даже такая страна, как Соединенные Штаты, вынуждена следовать правилу диссипации инклюзивности и не имеет волшебного иммунитета против всеобщей тенденции общества к экстрактивности.

В данной точке анализа мы подходим к вопросу об альтернативных способах построения эффективных инклюзивных институтов. Все известные ИИ не идеальны, однако построенные в США оказались наиболее впечатляющими и жизнеспособными. Тем не менее мировая история не прекращает свой эксперимент: сегодня Китай создает свою смешанную модель развития с экстрактивными политическими и во многом инклюзивными экономическими институтами и на ее основе ведет глобальную конкуренцию с США. Это свидетельствует о наличии смешанной институцииональной модели, в которой экстрактивность политических институтов присутствует на фоне некоторой инклюзивности экономических институтов. В литературе уже высказывалась идея, согласно которой наиболее жизнеспособными являются смешанные институты [Балацкий, 2015]. Будущее покажет, сможет ли Китай обеспечить эффективность такой институциональной модели в долгосрочном аспекте. Не исключено, что наличие определенной и меняющейся во времени дозы экстрактивности политических институтов будет благотворно сказываться на социальном развитии страны.

Что касается России, то само крушение СССР во многом имело своей целью закрепление привилегий правящей элиты, что последовательно осуществлялось на протяжении четверти века с учетом всевозможных случайностей в становлении элиты и межклановой борьбы в ее рядах. Сегодня как никогда ранее стал очевиден паралич социальных лифтов; в кругах политической и административной элиты наблюдается бесконечная ротация одних и тех же лиц. Все это свидетельствует об утверждении в стране экстрактивных политических и экономических институтов, что ставит перед современной Россией проблему проведения срочной модернизации не только в технологическом плане, но прежде всего в плане институциональном и социокультурном. В противном случае российское общество рискует оказаться на обочине экономического развития, поскольку современный уровень технологий и сама атмосфера инновационных преобразований немыслимы без опоры на соответствующие их духу социокультурные 
компоненты и комплекс инклюзивных институтов. В последнее же десятилетие мы наблюдаем последовательное укрепление экстрактивных институтов, дающих некую стабильность, но в то же время порождающих застой в наиболее перспективных видах деятельности.

Однако при всех проблемах, связанных с «утечкой мозгов», обусловленной прежде всего этим застоем, нельзя не видеть и того, что сегодня меньшинство населения (обычно фиксируемое на уровне 15-20\%) постепенно формирует ту «инклюзивную ауру» из специалистов, обладающих и соответствующими знаниями, и наработанным в нишах сложной социальной структуры опытом; именно эти люди способны начать выстраивать сеть инклюзивных институтов. Подобная работа требует не только их самоотверженного труда, но и серьезного политического переосмысления всей социально-экономической и структурной политики, иначе успех 2000-х гг, основанный на притоке нефтедолларов, так же быстро может сойти на нет, как и успехи советской индустриализации.

\section{Литература}

Аджемоглу Д., Робинсон Д. (2016) Почему одни страны богатые, а другие бедные. Происхождение власти, процветания и нищеты. М.: АСТ.

Алесина А., Джулиано П. (2016) Культура и институты. Часть I // Вопросы экономики. № 10. С. 82-111.

Асемоглу Д., Робинсон Д. (2015) Экономические истоки диктатуры и демократии. М.: ВШЭ.

Аузан А.А. (2007) «Колея» российской модернизации // Общественные науки и современность. № 6. С. 54-60.

Аузан А., Келимбетов К. (2012) Социокультурная формула экономической модернизации // Вопросы экономики. № 5. С. 37-44.

Ахиезер А.С. (1997) Россия: критика исторического опыта. Т. І. От прошлого к будущему. Новосибирск: Сибирский хронограф.

Ахиезер А.С. (1998) Россия: критика исторического опыта. Т. II. Теория и методология. Словарь. Новосибирск: Сибирский хронограф.

Балацкий Е.В. (2010) Кризис социальных наук в свете концепции старых рынков // Социологический журнал. № 2. С. 118-133.

Балацкий Е.В. (2015) Институциональные факторы экономического роста // Мир России. T. 24. № 2. С. 177-188.

Жаворонков С.В., Яновский К.Э. (2016) Испытание абсолютной монархии Романовых Мировой войной (Листая Особые журналы) // Общественные науки и современность. № 4. C. 109-119.

Кузнецова Р.В. (2016) Курчатов. М.: Молодая гвардия.

Миронов Б.Н. (2017) Российский пролетарий начала XX века - революционный авангард, гегемон или маргинал? // Общественные науки и современность. № 3. С. 97-119.

Миронов Б.Н. (2000) Социальная история России периода империи (XVIII - начало $\mathrm{XX}$ века). Генезис личности, демократической семьи, гражданского общества и правового государства. В 2 т. СПб.: Дмитрий Буланин.

Народное хозяйство СССР в 1987 г. Статистический ежегодник (1988) М.: Финансы и статистика.

Норт Д. (2010) Понимание процессов экономических изменений. М.: ВШЭ.

Норт Д., Уоллис Д., Вайнгаст Б. (2011) Насилие и социальные порядки. Концептуальные рамки для интерпретации письменной истории человечества. М.: Издательство Института Е. Гайдара. 
Плискевич H.M. (2016) Path dependence и проблемы модернизации мобилизационного типа // Мир России. Т. 25. № 2. С. 123-143.

Полтерович В.М. (2002) Политическая культура и трансформационный спад. Комментарий к статье Арье Хиллмана «В пути к земле обетованной» // Экономика и математические методы. Т. 38. № 4. С. 95-103.

Полтерович В.М. (2016) Институты догоняющего развития (к проекту новой модели экономического развития России) // Экономические и социальные перемены: факты, тенденции, прогноз. № 5. С. 88-107.

Рыжов Ю. (2016) Россия стоит на пороге жуткого краха // Московский комсомолец, 25.12.2016 // http://www.mk.ru/science/2016/12/25/akademik-yuriy-ryzhov-rossiya-stoitna-poroge-zhutkogo-krakha.html

Соловьев Ю.И. (1995) Мужественная позиция академика Д.Н. Прянишникова // Куманев B.А. (ред.) Трагические судьбы: репрессированные ученые Академии наук СССР. М.: Наука.

Франкфурт С.М. (1935) Рождение стали и человека. М.: Старый большевик.

Харрисон Л. (2014) Евреи, конфуцианцы и протестанты. Культурный капитал и конец мультикультурализма. М.: Мысль.

\title{
Economic Growth under Extractive Institutions: the Soviet Paradox and Contemporary Events
}

\author{
E. BALATSKY*, N. PLISKEVICH**
}

\begin{abstract}
*Evgeny Balatsky - Doctor of Science of Economics, Professor, Director of the Centre for Macroeconomic Research, Financial University under the Government of the Russian Federation. Address: room 219, 4, 4th Veshnyakovskij Passage, Moscow, 109456, Russian Federation. E-mail: evbalatsky@inbox.ru

**Natalya Pliskevich - Senior Researcher, Institute of Economics, Russian Academy of Sciences. Address: 26, Maronovskij Lane, Moscow, 119049, Russian Federation. E-mail: ons@naukaran.ru
\end{abstract}

Citation: Balatsky E., Pliskevich N. (2017) Economic Growth under Extractive Institutions: the Soviet Paradox and Contemporary Events. Mir Rossii, vol. 26, no 4, pp. 97-117 (in Russian). DOI: 10.17323/1811-038X-2017-26-4-97-117

\begin{abstract}
This article investigates the economic success of the USSR in terms of the concept of inclusive institutions (CII) developed by Acemoglu and Robinson. It avoids the problem that the original concept is not well suited for offering a systematic explanation of the Soviet paradox, that is, its long and intensive economic growth under conditions of extractive political institutions. The article clarifies and develops some of the problematic aspects of CII to achieve a more precise and consistent explanation of the paradox. In particular, it introduces some missing supplemental concepts, such as social lifts (as the main criterion of inclusive institutions), regimes of catch-up and advanced economic growth;
\end{abstract}


a three-factor economic growth model which includes technological, institutional and cultural factors; the principle of the compatibility between developmental factors; and the principle of dissipating inclusiveness. This more comprehensive conceptual framework allows for a more consistent explanation of the USSR's history from its formation until its eventual collapse. The framework itself is also well suited for explaining the success of other oil producing countries in the Middle East.

Key words: inclusive institutions, extractive institutions, Soviet industrialization, economic growth, modernization, social lifts

\section{References}

Akhiezer A.S. (1997) Rossiya: kritika istoricheskogo opyta (Sotsiokulturnaya dinamika Rossii). T. I. Ot proshlogo k budushchemu [Russia: a Critique of Historical Experience (Sociocultural Dynamics of Russia), vol. I. From the Past to the Future], Novosibirsk: Sibirskij khronograf. Akhiezer A.S. (1998) Rossiya: kritika istoricheskogo opita. T.II. Teoriya i metodologiya. Slovar'

[Russia: a Critique of Historical Experience (Sociocultural Dynamics of Russia), vol. II. Theory and Methodology. Dictionary], Novosibirsk: Sibirskij khronograf.

Alesina A., Dzhuliano P. (2016) Kultura i instituti. Chast I [Culture and Institutions. Part I]. Voprosi ekonomiki, no 10, pp. 82-111.

Asemoglu D., Robinson D. (2015) Ekonomicheskie istoki diktaturi i demokratii [Economic Origins of Dictatorship and Democracy], Moscow: HSE.

Asemoglu D., Robinson D. (2016) Pochemu odni strani bogatye, a drugie bednye. Proiskhozhdenie vlasti, protsvetaniya $i$ nischeti [Why Nations Fail. The Origins of Power, Prosperity, and Poverty], Moscow: AST.

Auzan A.A. (2007) «Koleya» rossijskoj modernizatsii [The 'Gauge' of Russian Modernization]. Obshchestvennye nauki i sovremennost', no 6, pp. 54-60.

Auzan A., Kelimbetov K. (2012) Sotsiokul'turnaya formula ekonomicheskoj modernizatsii [A Socio-cultural Formula for Economic Modernization]. Voprosy ekonomiki, no 5, pp. 37-44.

Balatsky E.V. (2010) Krizis sotsial'nykh nauk v svete kontseptsii starikh rinkov [The Crisis of Social Sciences in Light of the Concept of Old Markets]. Sotsiologicheskij zhurnal, no 2, pp. 118-133.

Balatsky E.V. (2015) Institutsional'nye faktory ekonomicheskogo rosta [Institutional Factors of Economic Growth]. Mir Rossii, vol. 24, no 2, pp. 177-188.

Frankfurt S.M. (1935) Rozhdenie stali $i$ cheloveka [The Birth of Steel and Man], Moscow: Staryj bol'shevik.

Harrison L. (2014) Evrei, konfutsiantsy i protestanty. Kulturnij kapital i konets multikul'turalizma [Jews, Confucians, and Protestants. Cultural Capital and the End of Multiculturalism], Moscow: Misl'.

Kuznetsova R.V. (2016) Kurchatov [Kurchatov], Moscow: Molodaya gvardiya.

Mironov B.N. (2017) Rossijskij proletarij nachala XX veka revolyutsionnij avangard, gegemon ili marginal? [Russian Proletarians at the Beginning of the Twentieth Century -Revolutionary Pioneers, Hegemons or Outcasts?] Obschestvennye nauki i sovremennost', no 3, pp. 97-119.

Mironov B.N. (2000) Sotsial'naya istoriya Rossii perioda imperii (XVIII nachalo - XX veka). Genezis lichnosti, demokraticheskoj sem'i, grazhdanskogo obshchestva i pravovogo gosudarstva. V 2 t. [Social History of Russia in the Empire Period (XVIII - early XX century). A Genesis of Personality, Democratic Family, Civil Society and the Rule of Law. In 2 Vols.], Saint-Petersburg: Dmitrij Bulanin.

Narodnoe hozyaystvo SSSR v 1987 g. Statisticheskij ezhegodnik (1988) [The National Economy of the USSR in 1987. Statistical Yearbook], Moscow: Finansy i statistika. 
North D. (2010) Ponimanie protsessov ekonomicheskikh izmenenij [Understanding the Process of Economic Change], Moscow: HSE.

North D., Wallis J., Weingast B. (2011) Nasilie i sotsial'nye poryadki. Kontseptualnye ramki dlya interpretatsii pismennoi istorii chelovechestva [Violence and Social Orders. A Conceptual Framework for Interpreting Recorded Human History], Moscow: Institut Gaydara.

Pliskevich N. (2016) 'Path Dependence' i problemy modernizatsii mobilizatsionnogo tipa ['Path Dependence' and the Problem of Modernization from Above]. Mir Rossii, vol. 25, no 2, pp. 123-143.

Polterovich V.M. (2002) Politicheskaya kul'tura i transformatsionnij spad. Kommentarij k stat'e Are Hillmana «V puti k zemle obetovannoj» [Political Culture and Failing Transformation. A Commentary on Arieh Hillman's Article "On the Road to the Promised Land"]. Ekonomika i matematicheskie metody, vol. 38, no 4, pp. 95-103.

Polterovich V.M. (2016) Instituti dogonyayushchego razvitiya (k proektu novoj modeli ekonomicheskogo razvitiya Rossii) [Institutions of Catch-up Development (Towards the Project of a New Model of Russia's Economic Development)]. Ekonomicheskie i sotsial'nie peremeny: fakti, tendentsii, prognoz, no 5, pp. 88-107.

Ryzhov YU. (2016) Rossiya stoit na poroge zhutkogo krakha [Russia at the Brink of a Terrible Collapse]. Moskovskij komsomolets, 25 December 2016. Available at: http://www.mk.ru/ science/2016/12/25/akademik-yuriy-ryzhov-rossiya-stoit-na-poroge-zhutkogo-krakha. html, accessed 31 August 2017.

Solovev Yu.I.(1995) Muzhestvennaya pozitsiya akademika D.N. Pryanishnikova [The Courageous Stand of Academician D.N. Pryanishnikov]. Tragicheskie sudbi: repressirovannie uchenie Akademii nauk SSSR [Tragic Destinies: the Repressed Scientists of the USSR Academy of Sciences] (ed. Kumanev V.A.), Moscow: Nauka.

Zhavoronkov S.V., Yanovskij K.E. (2016) Ispytanie absolyutnoj monarkhii Romanovikh Mirovoj vojnoj (Listaya Osobye zhurnaly) [The Romanovs' Absolute Monarchy against the Test of the World War (a Study through Special Journals)]. Obshchestvennie nauki i sovremennost', no 4. pp. 109-119. 